\title{
Evaluasi Penerapan Program Adiwiyata Untuk Membentuk Perilaku Peduli Lingkungan di Kalangan Siswa (Kasus: SMA Negeri 9 Tangerang Selatan dan MA Negeri 1 Serpong)
}

\author{
Rizky Dewi Iswari*, Suyud W. Utomo \\ Jurusan Ilmu Lingkungan, Sekolah Ilmu Lingkungan, Universitas Indonesia, \\ *Corresponding author: rizky.iswari@gmail.com
}

\begin{abstract}
ABSTRAK
Perilaku peduli lingkungan masih sangat minim, termasuk di kalangan siswa. Salah satu upaya untuk membentuk perilaku peduli lingkungan di kalangan siswa yaitu melalui penerapan program Adiwiyata melalui pendidikan formal pada semua jenjang sekolah. Permasalahannya, penerapan program Adiwiyata yang telah dilakukan ternyata belum menjamin terbentuknya perilaku peduli lingkungan warga sekolah. Atas dasar deksripsi tersebut, maka tujuan dari penelitian yaitu menganalisis hubungan Adiwiyata dalam upaya pembentukan perilaku peduli lingkungan, ditinjau dari aspek pengetahuan, sikap, dan tindakan siswa. Metode yang digunakan dalam penelitian ini yaitu deskriptif kualitatif. Hasil riset di sekolah yang sudah Adiwiyata menunjukkan sebesar 48\% siswa tingkat pengetahuannya tinggi, 99\% siswa mempunyai sikap baik terhadap lingkungan, dan 79\% siswa mempunyai tindakan baik terhadap lingkungan. Adapun sekolah yang belum Adiwiyata, sebesar 33\% siswa tingkat pengetahuannya tinggi, 99\% siswa mempunyai sikap baik terhadap lingkungan, dan $76 \%$ siswa mempunyai tindakan baik terhadap lingkungan. Dengan demikian terdapat hubungan antara penerapan Adiwiyata dengan pembentukan pengetahuan, sikap dan tindakan di kalangan siswa.
\end{abstract}

Kata kunci: Adiwiyata, perilaku peduli lingkungan, pengetahuan, sikap, tindakan

\begin{abstract}
Behavior of environmental awareness is still low, even among students. One effort to create behavior of environmental awareness among students through Adiwiyata program, which is integrate in formal education at all, levels of school. The problem is, application of Adiwiyata program can't guarantee to create behavior awareness. Based on that descriptions, purpose of this study is to evaluate implementation of Adiwiyata program, comparing student's behavior in two different school, and to analyze the relationship between Adiwiyata and behavior of environmental awareness from three aspect, knowledge, attitude, and action. The method used in this research is descriptive qualitative. The result showed, Adiwiyata school have 48\% students with high knowledge, 99\% students with good attitudes, and $79 \%$ students with good action toward environment. In other hand, non Adiwiyata school have 33\% students with high knowledge, 99\% students with good attitudes, and 76\% students with good action toward environment. Thus, there is relationship between implementation of Adiwiyata program to build knowledge, attitude and action toward environment.
\end{abstract}

Keywords: Adiwiyata, behavior of environmental awareness, knowledge, attitude, action

Citation: Iswari, R.D, dan Utomo, S.W. (2017). Evaluasi Penerapan Program Adiwiyata Untuk Membentuk Perilaku Peduli Lingkungan di Kalangan Siswa (Kasus: SMA Negeri 9 Tangerang Selatan dan MA Negeri 1 Serpong). Jurnal Ilmu Lingkungan, 15(1), 35-41, doi:10.14710/jil.15.1.35-41

\section{Latar Belakang}

Aktivitas manusia adalah salah satu unsur yang menentukan kualitas lingkungan hidup. Banyaknya kerusakan lingkungan yang diakibatkan oleh faktor antropogenik mendorong adanya upaya untuk melakukan perbaikan lingkungan. Pentingnya isu lingkungan dimulai dari abad ke-19 yang memunculkan berbagai aksi dari berbagai negara. Indonesia menjadi salah satu negara yang juga menaruh perhatian dalam upaya pengelolaan lingkungan. Hal ini dibuktikan dengan adanya
Undang-Undang Nomor 32 Tahun 2009 tentang Perlindungan dan Pengelolaan Lingkungan Hidup yang isinya mencakup perencanaan, pemanfaatan, pengendalian, pemeliharaan, sampai pada pengawasan dan penegakkan hukum (Keraf, 2010).

Perilaku manusia adalah faktor utama yang menyebabkan kerusakan lingkungan secara global. Hal ini disebabkan oleh perilaku peduli lingkungan masih sangat minim, khususnya di Indonesia. Salah satu upaya yang dilakukan pemerintah Indonesia untuk meningkatkan perilaku kepedulian lingkungan 
yaitu dengan mengadakan Pendidikan Lingkungan Hidup (PLH) di dalam dunia pendidikan. Munculnya kepedulian PLH dimulai pada tahun 1975, pada saat itu pendidikan lingkungan dikaitkan dengan pendidikan kependudukan dan lingkungan hidup. Hal ini telah diuji cobakan pada 15 Sekolah Dasar (SD) di DKI Jakarta (Soerjani et al., 2007). Pada tahun 1986 PLH mulai diintegrasikan ke dalam kurikulum di beberapa SD, SMP, SMA dan SMK di seluruh Indonesia. Setelah dievaluasi pada tahun 2002, pelaksanaan tersebut dinilai kurang berhasil karena beberapa faktor, antara lain belum adanya standar baku PLH, kurangnya koordinasi antarsekolah dan para pengajarnya (Soerjani et al., 2007).

Pendidikan lingkungan adalah salah satu upaya untuk memberikan pengetahuan lingkungan di kalangan pelajar sekolah. Hal ini ditujukan dengan asumsi bahwa jika pengetahuan tentang lingkungan meningkat, maka perilaku peduli lingkungan juga meningkat dan akan mengurangi kerusakan lingkungan di masa yang akan datang. Menurut Akpan et al. (2003) menyatakan konsep dasar dalam membentuk perilaku peduli lingkungan dibutuhkan tiga unsur, yaitu faktor institusional, strategi pendidikan, serta pengetahuan dan nilai. Ketiga faktor tersebut berkaitan satu dan yang lainnya. Faktor institusi berhubungan dengan kebijakan politik, ketersediaan dana dan fasilitas yang berkaitan dengan pengelolaan lingkungan. Strategi pendidikan adalah salah satu hasil dari kebijakan yang ditujukan untuk meningkatkan pengetahuan dan nilai yang nantinya akan mempengaruhi perilaku peduli lingkungan.

Program Adiwiyata dapat dilaksanakan secara optimal sejak tahun 2010 seiring dengan adanya kebijakan baru yang menggantikan kebijakan sebelumnya antara Menteri Lingkungan Hidup dan Menteri Pendidikan Nasional melalui kesepakatan bersama No.03/MenLH/02/2010. Hal ini kemudian dikuatkan lagi dengan adanya Peraturan Menteri (Permen) Lingkungan Hidup Nomor 5 Tahun 2013 tentang Pedoman Pelaksanaan Program Adiwiyata. Tujuan dari program Adiwiyata berdasarkan pada Permen tersebut yaitu untuk mewujudkan sekolah yang peduli dan berbudaya lingkungan, pelaksanaanya berdasarkan tiga prinsip yaitu edukatif, partisipatif, dan berkelanjutan.

Program Adiwiyata adalah program yang komprehensif melibatkan semua stakeholders baik di sekolah dan masyarakat untuk membantu meningkatkan kepedulian lingkungan, khususnya para siswa. Menurut Permen Adiwiyata Nomor 5 Tahun 2013 tujuan program yang hendak dicapai dijabarkan dalam empat komponen utama, yaitu: (1) aspek kebijakan sekolah yang berwawasan lingkungan; (2) aspek kurikulum sekolah berbasis lingkungan; (3) aspek kegiatan sekolah berbasis partisipatif; dan (4) aspek pengelolaan sarana dan prasarana pendukung sekolah yang ramah lingkungan. Komponen 1 dan 2 merupakan kewenangan dan kebijakan dari Kementerian Pendidikan dan Kebudayaan sedangkan komponen 3 36 dan 4 merupakan kewenangan dan kebijakan Kementerian Lingkungan Hidup.

Faktanya, keberadaan program Adiwiyata ini belum dapat menjamin sepenuhnya peningkatan kepedulian lingkungan di kalangan pelajar. Berdasarkan penelitian Landriany (2014) menyatakan bahwa Adiwiyata belum berhasil dilaksanakan di SMA Kota Malang. Hal ini dikarenakan beberapa faktor, antara lain beberapa siswa masih belum paham mengenai konsep sekolah berwawasan lingkungan, beberapa diantaranya masih tidak peduli dengan kondisi lingkungan, kurangnya peran serta masyarakat, dan kurangnya antusias penerapan PLH di kalangan guru dan karyawan sekolah. Hasil penelitian serupa dikemukakan Sudarwati (2012) menyatakan bahwa penerapan Adiwiyata di SMA N 11 Semarang tidak berjalan dengan baik disebabkan kurangnya komunikasi antara pihak sekolah dan penganggung jawab program, sumber daya manusia yang masih rendah, dan sumber dana yang belum cukup untuk melaksanakan program Adiwiyata.

Penelitian yang dilakukan oleh (Rahmawati dan Suwanda, 2015) menunjukkan bahwa Adiwiyata tidak dapat terlaksana secara efektif dikarenakan adanya pergantian siswa setiap tahun ajaran baru, keadaan sosial ekonomi siswa, dan kepedulian pendidik. Hal ini kemudian berdampak pada sulitnya pembentukan perilaku peduli lingkungan siswa. Salah satu sekolah yang mendapat gelar Adiwiyata Mandiri adalah SMA Negeri 9 Tangerang Selatan sejak tahun 2013. Peneliti memandang penting untuk dilakukan analisis mendalam apakah program Adiwiyata sudah mampu atau belum untuk membentuk perilaku peduli lingkungan di kalangan siswa baik di dalam maupun luar sekolah.

Pendidikan adalah salah satu variabel paling penting dalam membentuk perilaku peduli lingkungan, semakin tinggi pengetahuan seseorang maka semakin peduli pada permasalahan lingkungan (Molina et al., 2013). Pendidikan lingkungan adalah suatu proses yang bertujuan membentuk perilaku, nilai, dan kebiasaan untuk menghargai lingkungan hidup (Wirakusumah, 2010). Salah satu strategi dalam pendidikan ini diaplikasikan dalam program Adiwiyata di lingkungan sekolah. Adiwiyata memuat empat komponen utama yang komprehensif untuk mewujudkan sekolah yang berbudaya lingkungan, tidak hanya dari segi fisik sekolah saja namun dari perilaku warga sekolahnya.

Program Adiwiyata yang diaplikasikan di beberapa sekolah bertujuan untuk mewujudkan sekolah yang peduli dan berbudaya lingkungan. Berdasarkan hasil penelitian sebelumnya didapatkan kesimpulan bahwa sekolah yang bergelar Adiwiyata belum menjamin untuk mewujudkan pemahaman yang baik mengenai lingkungan, serta sikap dan tindakan yang mencerminkan kepedulian lingkungan. Hal ini bertolak belakang dengan apa yang disampaikan oleh tim pembina sekolah Adiwiyata BLHD Tangerang Selatan, bahwa sekolah yang sudah dibina menunjukkan tingkat kepedulian lingkungan 
lebih tinggi daripada yang belum dibina. Kepedulian tersebut dilihat dari tingkat pengetahuan, sikap dan tindakan siswa dalam mengelola dan melestarikan lingkungan hidup (Safitri, 2015). Berdasarkan pemaparan sebelumnya, maka pertanyaan penelitian dijabarkan sebagai berikut:

1. Bagaimana evaluasi penerapan program Adiwiyata berdasarkan standar pencapaian Adiwiyata di SMA Negeri 9 Tangerang Selatan?

2. Bagaimana perbedaan perilaku peduli lingkungan dilihat dari tingkat pengetahuan, sikap, dan tindakan di kalangan siswa SMA Negeri 9 Tangerang Selatan dan MA Negeri 1 Serpong?

3. Bagaimana hubungan antara program Adiwiyata dengan pembentukan pengetahuan, sikap, dan tindakan di kalangan siswa?

\section{Metode}

Penelitian ini menggunakan pendekatan kuantitatif karena data berupa nilai dari variabel yang terukur. Metode yang digunakan adalah metode kuantitatif dan kualitatif dengan menggunakan data primer dan data sekunder. Data primer didapatkan dari hasil kuesioner, wawancara, dan observasi langsung. Data sekunder diperoleh dari mengkaji literatur, laporan evaluasi Adiwiyata dari BLHD Tangerang Selatan dan data yang relevan dari pihak sekolah.

\section{Hasil dan Pembahasan}

\subsection{Evaluasi Program Adiwiyata Di SMA N 9 Tangerang Selatan}

Sekolah SMA Negeri 9 adalah SMA negeri pertama yang mendapatkan gelar Adiwiyata Mandiri pada tahun 2013. Pada tahun 2014 sekolah ini kemudian mendapatkan penghargaan dari Kementerian Lingkungan Hidup (KLH) Indonesia sebagai Pusat
Edukasi Lingkungan Hidup. Selain mempunyai fasilitas sekolah yang bersifat umum, SMA Negeri 9 juga mempunyai beberapa fasilitas yang berkaitan dengan upaya pengelolaan lingkungan, seperti taman sekolah, taman kompos, taman toga, biopori, tempat sampah terpisah, dan lain sebagainya. Fasilitas sekolah tersebut sebagian besar terawat dan digunakan sebagai sarana pembelajaran bagi siswa.

Hasil observasi peneliti mengenai penerapan Adiwiyata di SMA Negeri 9 Tangerang Selatan dilihat dari 18 indikator. Peneliti menggunakan lembar checklist untuk melihat kesesuaian penerapan Adiwiyata di lapangan dengan lembar penilaian yang sudah dibuat peneliti. Hasil obervasi didapatkan skor total nilai 46 dari nilai maksimal 54. Nilai tersebut menunjukkan bahwa penerapan Adiwiyata di SMA Negeri 9 Tangerang Selatan tergolong baik. Hal ini menunjukkan $85 \%$ indikator penerapan Adiwiyata sudah terlaksana dengan baik. Bukti di lapangan juga menunjukkan bahwa SMA Negeri 9 Tangerang Selatan sangat mendukung upaya peningkatan perilaku peduli lingkungan di kalangan siswa dan warga sekolahnya.

\subsection{Perbandingan Tingkat Pengetahuan, Sika, Dan Tindakan Di SMA N 9 Tangsel Dan MAN 1 Serpong \\ Berdasarkan penjabaran sebelumnya, secara} keseluruhan tingkat pegetahuan dan tindakan siswa yang berkaitan dengan PPLH di SMA Negeri 9 Tangerang Selatan lebih tinggi dibandingkan dengan siswa di MA Negeri 1 Serpong sedangkan persentase sikap terhadap lingkungan, jumlahnya sama di kedua sekolah tersebut. Hasil tingkat pengetahuan siswa di kedua sekolah menunjukkan selisih perbedaan persentase yang cukup tinggi sedangkan untuk sikap tidak ada perbedaan sama sekali dan untuk tindakan perbedaanya hanya 3\% saja. Perbandingan hasil penelitian di kedua sekolah ditunjukkan Gambar 1.

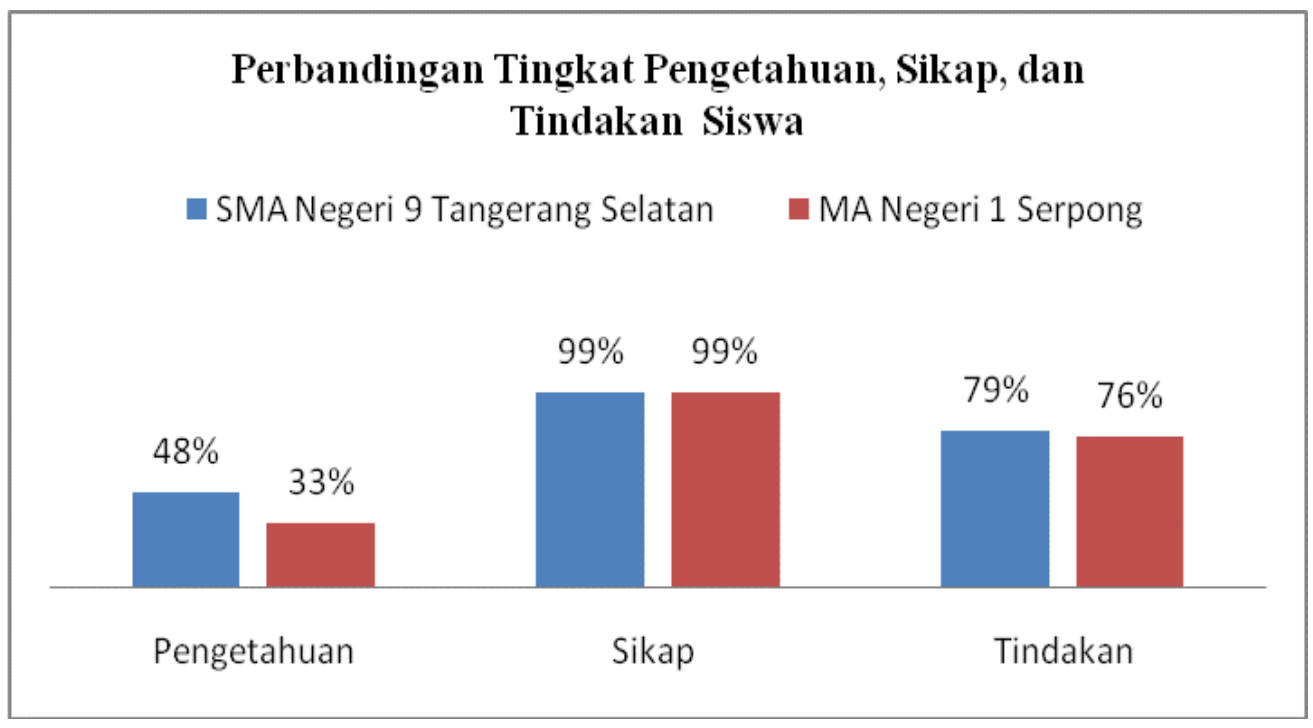

Gambar 1 Persentase Perbandingan Tingkat Pengetahuan, Sikap, dan Tindakan di SMA Negeri 9 dan MA Negeri 1 
Berdasarkan Gambar 1 yang terlihat perbedaan cukup jelas antara SMA Negeri 9 dan MA Negeri 1 yaitu tingkat pengetahuan. Siswa di SMA Negeri 9 memiliki tingkat pengetahuan tinggi dibandingkan dengan MA Negeri 1 dengan persentase masingmasing sekolah 48\% dan 33\%. Seperti yang sudah dijelaskan sebelumnya salah satu komponen penerapan Adiwiyata mendukung peningkatan pengetahuan LH. Hal ini dilihat dari dua komponen yaitu pengintegrasian lingkungan hidup ke dalam mata pelajaran wajib dan penggunaan metode belajar tenaga pendidik yang melibatkan siswa turut aktif. Kedua aspek tersebut tidak dijumpai penerapannya di MA Negeri 1 Serpong.

Di sisi lain, persentase tingkat pengetahuan siswa di MA negeri 1 Serpong juga tidak terlalu rendah akan tetapi tergolong sedang. Hal ini, menurut peneliti dapat disebabkan oleh beberapa faktor, yaitu siswa mendapatkan pengetahuan tentang lingkungan dari pihak lain, misalanya kegiatan ekstrakurikuler, informasi dari berbagai media atau pendididikan dari luar sekolah, dan sebagainya. Dengan demikian, meskipun tidak mendapatkan materi PLH secara langsung pada kegiatan pembelajaran, siswa masih mendapatkan informasi dan pengetahuan mengenai lingkungan hidup dari sumber yang lain. Oleh karena itu, masih ada beberapa siswa yang mempunyai pengetahuan tinggi terkait dengan lingkungan hidup meskipun jumlahnya sedikit.

Faktor lain yang diukur yaitu nilai sikap di kedua sekolah mempunyai hasil yang sama yaitu $99 \%$ siswa sudah mempunyai sikap yang baik terhadap lingkungan. Sikap siswa di SMA negeri 9 Tangerang Selatan baik karena memang didukung oleh PLH yang ada di sekolah tersebut serta faktor-faktor lain pembentuk sikap yang didukung dari adanya penerapan program Adiwiyata. Di sisi lain, sikap siswa MA Negeri Serpong terhadap lingkungan juga sebesar 99\%. Menurut peneliti, hal ini dipengaruhi oleh kondisi lingkungan sekolah yang berbasiskan agama sehingga siswa cenderung dibentuk persepsinya sesuai dengan nilai-nilai agama atau spiritual. Hal inilah yang kemudian memunculkan sikap peduli lingkungan yang baik. Hasil ini sejalan dengan teori Syarif (2009), Rusuli (2014) dan tujuan pendidikan nasional bahwa pentingnya untuk menanamkan nilainilai spiritual dalam pembelajaran untuk mewujudkan karakter yang utuh. Penanaman nilainilai spiritual berfungsi untuk mendorong individu melakukan aktivitas semata-mata untuk melaksanakan perintah Tuhan, selain itu nilai spritual ini juga penting untuk mewujudkan individu yang mempunyai tanggung jawab moral dan sosial di masyarakat.

Aspek terakhir yang juga berpengaruh terhadap perilaku adalah tindakan. Aspek ini sangat dipengaruhi oleh adanya sarana dan prasarana yang mendukung seseorang untuk bertindak. Dengan demikian, wajar apabila persentase siswa yang melakukan tindakan baik terhadap lingkungan di SMA Negeri 9 lebih tinggi dibandingkan dengan MA Negeri 38
1 Serpong dengan persentase masing-masing sekolah yaitu 79\% dan 76\%. Hal ini karena lengkapanya ketersediaan sarana prasarana yang berkaitan dengan PPLH di SMA Negeri 9 seperti tempat sampah terpisah, taman sekolah, green house, biopori, dan lain sebagainya. Di lain pihak, perbedaan persentase antara kedua sekolah tidak terlalu jauh, hanya selisih $3 \%$ saja meskipun kelengkapan sarana prasarana di kedua sekolah tersebut sangat berbeda jauh.

Peneliti menganalisis kemungkinan ada dua faktor yang menyebabakan hal tersebut, yaitu: (1) kuesioner diisi oleh responden MA Negeri 1 Serpong secara normatif, dalam artian responden tidak menjawab pertanyaan dengan serius melainkan dengan jawaban yang ideal; (2) ada faktor lain yang berpengaruh terhadap tindakan siswa. Peneliti berasumsi bahwa tindakan siswa dipengaruhi oleh faktor lain selain ketersediaan sarana prasarana dan kebijakan sekolah. Sesuai dengan Teori Triandhy yang dikemukakan Jackson (2005) dan teori dari Kollmuss dan Agyeman (2002) bahwa tindakan individu sangat kompleks karena melibatkan faktor-faktor internal dan eksternal yang saling berkaitan. Dengan demikian, tindakan siswa di MA Negeri 1 Serpong dapat dipengaruhi oleh sikap (99\% siswa mempunyai sikap baik terhadap lingkungan), faktor kebiasaan, kondisi lingkungan sosial dan budaya di sekolah.

\subsection{Hubungan Program Adiwiyata Dan Perilaku Peduli Lingkungan}

Berdasarkan hasil penelitian secara keseluruhan didapatkan bahwa penerapan Adiwiyata di SMA Negeri 9 sudah tergolong baik dengan tingkat pencapaian 85\%. Di sisi lain, hasil pengukuran tingkat pengetahuan, sikap dan tindakan siswa di sekolah tersebut masing-masing aspek menunjukkan persentase lebih tinggi (kecuali aspek sikap karena persentasenya sama dengan MA Negeri 1 Serpong) yaitu dengan nilai 48\%, 99\%, dan 79\%. Dengan demikian, dapat disimpulkan bahwa ada hubungan antara penerapan program Adiwiyata dengan pembentukan pengetahuan, sikap dan tindakan yang berkaitan dengan peduli lingkungan di kalangan siswa. Sebagai perbandingan, sekolah yang tidak menerapakan Adiwiyata mempunyai hasil yang berbeda terutama dari segi tingkat pengetahuan dan tindakan siswa.

Adiwiyata adalah program yang bertujuan untuk mewujudkan warga sekolah yang bertanggung jawab dalam upaya perlindungan dan pengelolaan lingkungan hidup. Hal ini sesuai dengan teori Krajhanzl (2010) yang menyatakan bahwa tujuan yang dimaksudkan program Adiwiyata tersebut sebagai bentuk perwujudan perilaku peduli lingkungan. Beberapa komponen Adiwiyata berkaitan langsung dalam pembentukan perilaku peduli lingkungan yang dijabarkan melalui tiga aspek, yaitu tingkat pengetahuan, sikap, dan perilaku. Pada teori sebelumnya dinyatakan bahwa faktor yang mempengaruhi perilaku peduli lingkungan sangat 
Iswari, R.D, dan Utomo, S.W. (2017). Evaluasi Penerapan Program Adiwiyata Untuk Membentuk Perilaku Peduli Lingkungan di Kalangan Siswa (Kasus: SMA Negeri 9 Tangerang Selatan dan MA Negeri 1 Serpong). Jurnal IImu Lingkungan, 15(1), 35-41, doi:10.14710/jil.15.1.35-41

kompleks dan melibatkan banyak aspek. Tidak ada jaminan bahwa salah satu dari tiga aspek tersebut baik, maka perilaku peduli lingkungannya juga baik, hasil penelitian juga sudah menunjukkan hasil serupa. Oleh karena itu, peneliti setuju dengan Meyer (2015) bahwa tidak selalu tingkat pengetahuan yang tinggi akan mendorong seseorang untuk berperilaku peduli lingkungan.

Sikap yang baik juga belum tentu mencerminkan tindakan atau perilaku yang baik pula. Hal ini dikembalikan lagi pada Teori Triandhy yang dikemukakan Jackson (2005) dan teori Kollmuss dan Agyeman (2002) bahwa pembentukan perilaku peduli lingkungan sangat kompleks karena melibatkan faktor-faktor internal dan eksternal yang saling berkaitan, di samping juga terdapat faktor penghalang seseorang untuk mengubah perilakunya. Dengan demikian, untuk mewujudkan perilaku peduli lingkungan tidak cukup hanya dengan melibatkan satu aspek pengubah saja atau pihak tertentu saja (misalnya sekolah saja) untuk melakukan perubahan tetapi dengan mempertimbangkan semua aspek yang terlibat dan kerjasama antar semua pihak.

Di sisi lain, pendidikan saat ini juga belum mampu mewujudkan individu yang dapat menerapkan nilai-nilai yang ada dalam Pancasila. Sejalan dengan teori Syarif (2009) dan Sabatin (2007) bahwa mengubah perilaku dibutuhkan adanya kaitan antara pemikiran, perasaan, serta adanya dorongan spriritual. Nilai-nilai yang ada dalam Pancasila belum sepenuhnya mampu mengakar ke dalam diri individu. Kaitannya dengan mewujudkan perilaku peduli lingkungan, maka sila ke-1 yaitu Ketuhanan Yang Mahaesa sudah menjadi alasan kuat yang mendorong seseorang untuk bertanggung jawab terhadap lingkungannya. Hal ini dikarenakan, perilaku peduli lingkungan adalah salah satu akhlak mulia yang diperintahkan oleh Tuhan sebagai wujud tanggung jawab manusia sebagai pemimpin (khalifah) di muka bumi. Berdasarkan hal tersebut, maka perlu dipertegas kembali tujuan dari pendidikan yang sebenarnya, termasuk pendidikan lingkungan hidup yang terintegrasi dalam Program Adiwiyata. Pendidikan lingkungan hidup harus fokus untuk mengubah perilaku individu dan bukan hanya sebatas mengubah pemahaman saja karena yang lebih penting adalah membangun jiwa dan karakter individu yang sesuai dengan nilai-nilai agama dan moral.

Berdasarkan hasil penelitian dan pembahasan yang dijabarkan sebelumnya, peneliti memberikan strategi untuk membentuk perilaku peduli lingkungan yang ditujukan kepada beberapa pihak. Berikut strategi yang disarankan berdasarkan hasil evaluasi penerapan Adiwiyata di SMA Negeri 9 Tangerang Selatan. Strategi teknis berupa pembuatan kebijakan yang tegas, khusunya diperuntukkan bagi tiga kementerian yaitu Kementerian Pendidikan dan Lingkungan Hidup serta Kementerian Komunikasi dan Informatika Republik Indonesia. Upaya yang dapat dilakukan oleh kementerian tersebut ada beberapa yaitu:

1. Evaluasi kembali mengenai indikator pencapaian Adiwiyata yang telah ditentukan karena berdasarkan analisis peneliti, masih ada beberapa komponen yang mempunyai kelemahan sehingga tidak dapat dilakukan evaluasi.

2. Mewajibkan semua sekolah di Indonesia untuk menerapkan program Adiwiyata karena selama ini hanya bersifat sukarela dari pihak sekolah, sehingga masih ada beberapa sekolah yang belum atau tidak mau untuk mengikuti program Adiwiyata. Oleh karena itu, perlu adanya kebijakan untuk mewajibkan semua sekolah pada semua tingkatan untuk menerapkan program Adiwiyata. Mengacu pada teori Thriandhy (Jackson, 2005) pembentukan perilaku akan lebih mudah jika didukung oleh faktor kebiasaan. Dengan demikian Adiwiyata pada tingkat TK akan berpengaruh dalam pembiasaan dan penanaman pengetahuan dan nilai-nilai yang berkaitan dengan pelestarian lingkungan.

3. Perlunya integrasi aspek-aspek spiritual dan moral dalam semua pembelajaran. Hal ini berlaku secara umum, tidak hanya dalam pembelajaran lingkungan hidup saja. Mengacu pada teori Rusuli (2014) pembelajaraan sekarang bersifat rasional empiris karena dibangun berdasarkan pandangan sekuler. Pembelajaran seperti ini akan menghasilkan peserta didik yang bertindak seperti robot. Hal ini pun sejalan dengan tujuan pendidikan nasional bahwa pentingnya untuk menanamkan nilai-nilai spiritual dalam pembelajaran untuk mewujudkan karakter yang utuh. Peneliti juga setuju teori Syarif (2009) bahwa aspek spiritual ini yang akan mendorong manusia untuk melakukan aktivitas sesuai tanggung jawabnya sebagai makhluk Tuhan yang Mahaesa.

4. Turut serta dalam memberikan pengetahuan dan informasi positif yang berkaitan dengan upaya PPLH. Informasi tersebut seharusnya diberikan secara intensif dan terus menerus kepada masyarakat melalui berbagai media, mulai dari $\mathrm{TV}$, radio, internet dan media cetak. Dengan demikian, masyarakat akan mendapatkan pengetahuan mengenai lingkungan dan paham mengenai apa yang harus dilakukan untuk turut serta menjaga lingkungan tersebut.

\section{Kesimpulan}

Berdasarkan hasil penelitian, maka kesimpulan yang dapat diambil adalah:

- $\quad$ Penerapan program Adiwiyata di SMA Negeri 9 Tangerang Selatan sudah baik dengan persentase pencapaian sebesar $85 \%$.

- Perilaku peduli lingkungan di kalangan siswa SMA Negeri 9 Tangerang Selatan dan MA Negeri 1 Serpong dari tingkat pengetahuan, sikap dan 
tindakan didapatkan hasil yang berbeda. Sekolah SMA Negeri 9 Tangerang Selatan, sebesar 48\% siswa tingkat pengetahuannya tinggi, 99\% siswa mempunyai sikap baik terhadap lingkungan, dan 79\% siswa mempunyai tindakan baik terhadap lingkungan. Adapun sekolah MA Negeri 1 Serpong sebesar $33 \%$ siswa tingkat pengetahuannya tinggi, 99\% siswa mempunyai sikap baik terhadap lingkungan, dan $76 \%$ siswa mempunyai tindakan baik terhadap lingkungan.

- Terdapat hubungan antara penerapan Adiwiyata dengan pembentukan pengetahuan, sikap dan tindakan di kalangan siswa.

\section{Saran}

Saran dalam penelitian ini adalah:

1. Pihak sekolah

a. Bagi sekolah yang sudah menerapkan Adiwiyata hendaknya senantiasa menjaga indikator pencapaian Adiwiyata agar terus berlangsung pelaksanaannya secara maksimal.

b. Bagi sekolah yang belum Adiwiyata hendaknya secara sukarela mengikuti program tersebut sebagai wujud komitmen sekolah untuk mencapai tujuan pendidikan nasional.

2. Kementerian Pendidikan dan Lingkungan Hidup serta Kementerian Komunikasi dan Informatika Republik Indonesia

a. Mengevaluasi kembali mengenai indikator pencapaian Adiwiyata yang telah ditentukan.

b. Membuat kebijakan untuk mewajibkan semua sekolah di Indonesia turut berpartisipasi dalam penerapan program Adiwiyata

c. Perlunya pembuatan kurikulum yang mengintegrasikan aspek-aspek spiritual dan moral dalam semua pembelajaran.

d. Memberikan pengetahuan dan informasi positif yang berkaitan dengan upaya PPLH melalui berbagai media sehingga dapat dimanfaatkan oleh semua lapisan masyarakat.

3. Semua lapisan masyarakat

a. Berpartisipasi aktif dalam pelestarian lingkungan.

b. Mematuhi semua perundangan yang berlaku mengenai pelestarian lingkungan.

c. Melakukan penelitian yang bertujuan untuk menciptakan inovasi baru dan memberikan solusi untuk menyelesaikan permasalahan lingkungan.

\section{DAFTAR PUSTAKA}

Akpan, I. et al. (2003). Strategies for promoting pro environmental behaviour among university of waterloo students. Skripsi. Universitas Waterloo.

Arianty, N. (2012). Tingkat kesadaran mahasiswa fakultas MIPA dalam membuang sampah sembarangan. Skripsi. Universitas Lambung Mangkurat.
Bachtra, R. (2012). Environmental education in secondary vocational education: a comparisonof five asian countries. Jakarta: Program Studi Ilmu Lingkungan Universitas Indonesia.

BLHD. (2014). Panduan menuju adiwiyata mandiri. Badan Lingkungan Hidup Tangerang Selatan.

Bloom, B.S., D.R. Krathwohl, \& B.B. Masia. (1984). Taxonomy of educational objectives: the classification of educational goals,volume 1. New York: Longman.

BSNP. (2006). Standar isi untuk satuan dasar dan menengastandar kompetensi dan kompetensi dasar SMA/MA. Jakarta: BSNP

BPS. (2013). Indikator perilaku peduli lingkungan hidup 2013. Jakarta: BPS.

BPS. (2015). Tangerang selatan dalam angka 2015. Tangerang Selatan: BPS.

Cunningham, W.P, Mary Ann C. (2012). Environmental science, a global concern, $12^{\text {th }}$ edition. United States: Mc Graw Hill.

Hasyim, C. (2010). Program adiwiyata sekolah peduli dan berbudaya lingkungan. Kementerian Lingkungan Hidup Republik Indonesia.

Hermani, N. (2014). The model: buku pengembangan diri spiritual ideologis untuk meraih sukses pribadi dan peradaban. Yogyakarta: IKKJ Publisher.

Indrawati, R. (2014). Implementasi pendidikan karakter pada program adiwiyata melalui kegiatan lingkungan berbasis partisipatif di SMK Negeri 1 Turen. Skripsi. Universitas Negeri Malang.

Istiadi, Y. (2015). Pendidikan lingkungan hidup terlupakan dalam kurikulum. http://www.unpak.ac.id/pdf/pendidikan_lingkungan _hidup_terlupakan_dalam_kurikulum.pdf, dikases 29 Desember 2015, pk 21.36 WIB.

KLH (2013). Perilaku masyarakat peduli lingkungan: survei tahun 2012. Kementerian Lingkungan Hidup Republik Indonesia.

Keraf, S. (2010). Etika lingkungan hidup. Jakarta: PT Kompas Media Nusantara.

Krajhanzl, J. (2010). Environmental and pro environmental behaviour. School and Health Journal, 21, 251-274.

Krathwohl, D. R. (2002). A revision of Bloom's taxonomy: an overview. The Ohio State University.

Landriany, E. (2014). Implementasi kebijakan adiwiyata dalam upaya mewujudkan pendidikan lingkungan hidup di SMA kota malang. Jurnal Kebijakan dan Pengembangan Pendidikan, 2, 82-88.

Meyer, A. (2015). Does education increase pro environmental behavior? Evidence froum Europe. Jurnal Ecological Economic, 116,108-121.

Monalisa. (2013). Program Adiwiyata dalam pengelolaan Lingkungan Sekolah di SMPN 24 Padang. Skripsi. Universitas Negeri Padang.

Rahmawati, I. dan M. Suwanda. (2015). Upaya pembentukan perilaku peduli lingkungan siswa melalui sekolah adiwiyata di SMP negeri 8 Surabaya. Jurnal kajian Moral dan Kewarganegaraan, 1, 71-78.

Rusuli, I. (2014). Refleksi teori belajar behavioristik dalam perspektif islam. Jurnal Pencerahan, 8, 38-54.

Sabatin, N. (2007). Dasar-dasar mendidik anak. Terjemahan dari Asasiyat Tarbiyah al-Athfal (Abdurrahman, Y., Penerjemah). Bogor: Al Azhar Press.

Safitri, I. (2015, Oktober 20). Wawancara pribadi.

Soerjani, M. et al. (2007). Lingkungan hidup (the living environment). Jakarta: IPPL.

Sudarwati, T.M. (2012). Implementasi kebijakan pendidikan lingkungan hidup sekolah menengah atas negeri 11 
Iswari, R.D, dan Utomo, S.W. (2017). Evaluasi Penerapan Program Adiwiyata Untuk Membentuk Perilaku Peduli Lingkungan di Kalangan Siswa (Kasus: SMA Negeri 9 Tangerang Selatan dan MA Negeri 1 Serpong). Jurnal Ilmu Lingkungan, 15(1), 35-41, doi:10.14710/jil.15.1.35-41

semarang menuju sekolah adiwiyata. Tesis. Universitas Diponegoro.

Syarif, F.N (2009). Al Quwwah Ar Ruhiyah: kekuatan spirit tanpa batas. Yogyakarta: ArBirr Press.

Wirakusumah. (2010). Konsep pendidikan lingkungan di sekolah: model uji coba sekolah berwawasan lingkungan. Bandung: FMIPA Universitas Pendidikan Indonesia 